\title{
Elżbieta Kaszuba
}

University of Wrocław

\section{THE DEVELOPMENT OF RADIO SERVICES IN THE SECOND POLISH REPUBLIC. SOCIAL, STRATEGIC AND POLITICAL RATIONALE}

\begin{abstract}
Summary: In the Second Polish Republic, to about the mid-twenties, radio broadcasting was only a technical innovation. A fundamental change in this area was carried out by a private-state company Polish Radio, after a nation-wide state license for "broadcasting", that is a radio for the masses, was granted to it, on August 18, 1925..Polish Radio launched the enduring native radio and began to realise a great project of development of radio services in the country. Stimulating the development of radio broadcasting, in addition to economic significance, gained social, strategic and political importance. Radio ensured the freedom of communication, therefore it could prove useful in supporting the process of unifying the newly recovered state and society and expanded the access of all social groups including an underprivileged social class because of poverty, illiteracy, living in remote areas and being removed from the centre in terms of advancement of civilization to the modern informative, educational and cultural medium. Moreover, Polish Radio was forced to respond to hostile propaganda broadcast by radio stations in neighbouring countries, mainly in Germany and Soviet Union and also in Lithuania. Finally, in terms of the development of radio services, the Second Polish Republic made considerable progress, creating a technical base from scratch and popularising radio among the masses.
\end{abstract}

Keywords: radio services development, education, propaganda, integration.

DOI: $10.15611 /$ eis.2014.1.09

At the end of World War I radio revolutionised communication and the transfer of information and at the same time rapidly spread around the world. In Poland, to about the mid-twenties, radio broadcasting was a technical innovation used primarily by the military and a small number of magazines and news agencies. In 1925, only about 170-200 radio sets were listed in official records and throughout the country there was no broadcasting station intended for a wider public ${ }^{1}$. Pioneering work

${ }^{1}$ Radio w Polsce w latach 1935-1938, ed. F. Pawliszak, Warszawa 1938, p. 139; S. Miszczak, Historia radiofonii i telewizji w Polsce, Wydawnictwo Komunikacji i Łączności, Warszawa 1972, p. 176; A. Paczkowski, Prasa polska w latach 1918-1939, PWN, Warszawa 1980, p. 323. 
in this area was carried out by the Polish Radio Engineering Association (Polskie Towarzystwo Radiotechniczne) which, together with a radio tube factory, launched a trial radio station in Warsaw and on February 1, 1925 began broadcasting a daily program ${ }^{2}$.The interesting initiative of a group of enthusiasts, however, failed to develop and thrive. A few months later, on August 18, 1925, a nation-wide state licence for "broadcasting", that is a radio for the masses, was granted to an association created especially for this purpose under the name of the Polish Radio (Polskie Radio S.A). However, the first broadcast of the company's regular radio program was aired on April 18, 1926, at 5 p.m., which is considered to be the official symbolic beginning of the enduring Polish radio ${ }^{3}$.

The model of the radio adopted in Poland was that of a monopolistic public utility institution. Polish Radio was a private-state company. It operated in a media system controlled by the government. In the twenties this control was purely formal but in the thirties it gradually began to be exercised and strengthened in line with the well-established mechanisms typical of authoritarian rule. The authorities were adamant to maintain the dominant position in the process of social communication ${ }^{4}$. In 1926, through the state enterprise "Polish Post, Telegraph and Telephone" the Treasury owned $40 \%$ of shares in the Polish Radio Joint Stock Company. The acquisition of a majority stake, equivalent to the actual nationalisation of the institution, in spite of maintaining its status as a capital association, took place in August 1935. As a result of continued purchases in 1935 and 1936 the state's participation increased to $96 \%{ }^{5}$

The new electronic medium aroused great curiosity. The first radio exhibition in the country, made available from June 2, 1926 at the Warsaw School of Cadets, was visited by over 70 thousand people in just two weeks ${ }^{6}$. As it was expected, the

${ }^{2}$ The aforementioned radio station installed in Warsaw at 25 Narbutta Street had a modest power of $0.5 \mathrm{~kW}$, and from February 1 to March 14, 1926 its daily broadcast lasted two hours. However, in only a few months it attracted almost five thousand listeners. Dziesięć lat Polskiego Radia, ed. W. Kłyszewski, Warszawa 1935, no pagination; M.J. Kwiatkowski, To już historia. Felietony o dziejach Polskiego Radia, Warszawa 1975, p. 61; M.J. Kwiatkowski, Narodziny Polskiego Radia. Radiofonia w Polsce w latach 1918-1929, Warszawa 1972, pp. 99-109.

${ }^{3}$ During this period, the power of the broadcasting station at Narbutta Street was increased to $1.5 \mathrm{~kW}$, and the program lasted about five hours a day, Dziesięć lat Polskiego Radia ....; M.J. Kwiatkowski, To już historia ..., pp. 41, 54, 61- 62; M.J. Kwiatkowski, Narodziny Polskiego Radia ..., pp. 163-166.

${ }^{4}$ More about the state's expansion in the area of mass media: E. Kaszuba, System propagandy państwowej obozu rządzacego w Polsce w latach 1926-1939, Torun 2004.

${ }^{5}$ Wniosek Ministra Poczt i Telegrafów z 22 VI 1935 r., AAN PRM Akta KEM 1920-1939, sygn. 1411, mikrofilm 27471; Radio w Polsce w latach 1935-1938..., p. 150; M.J. Kwiatkowski, Polskie Radio 1925-1939. Mała kronika, „Pamiętnik Teatralny” 1973, z. 3-4, p. 400; M.J. Kwiatkowski, Tu Polskie Radio Warszawa..., Warszawa 1980, pp. 236-239; R. Miazek, Przeminęło z radiem. Opowieść o Zygmuncie Chamcu - założycielu i pierwszym dyrektorze Polskiego Radia, Rzeszów 2005, pp. $206-208$.

A. Paczkowski, op. cit., p. 325.

${ }^{6}$ M.J. Kwiatkowski, Narodziny Polskiego Radia..., pp. 166-177; M.J. Kwiatkowski, Tu Polskie Radio Warszawa..., pp. 90-96. 
enthusiasm of audience for the radio was reflected in a sharp increase in demand for radio sets. In 1926 the number of radio subscribers increased from 5200 to 42592 . In a little over two years, in April 1929, 202561 radio receivers were registered in Poland ${ }^{7}$. The quoted numbers assessed in relation to the total population were low. A comparison with other countries leads to similar conclusions. Germany, which started broadcasting two years earlier, had six times more radio sets at that time. Polish broadcasting did not reach a satisfactory growth rate and therefore, needed a strong impulse for development.

Because of the looming impasse, the technical management of the PR returned to their own perspective "Great radio network development plan in Poland," which was drafted as early as 1926 . The primary objective of the promoters - who believed it conditioned the country's participation in the international radio "power race" - was the construction of twelve broadcasting stations forming a tight umbrella covering all Polish territory. In addition to the existing stations - the one in Warsaw inaugurating the Polish Radio, and the ones prepared to be launched in Cracow and Poznan - it was planned to gradually add new ones: in Gdynia, Grudziądz, Katowice, Lublin, Lviv, Łódź, Rivne, Vilnius and Volkovysk ${ }^{8}$.

Two years later, the PR executives decided to bring the project of comprehensive national radio services to life in a slightly altered form. The differences related to the distribution and power of Polish radio stations already designed using the latest technology in the field of world radio engineering. At that time five radio stations operated in the country (Warsaw, Cracow, Poznan, Katowice and Vilnius), of which only two had more power - the one in Warsaw with $10 \mathrm{~kW}$ and the one in Katowice with $12 \mathrm{~kW}$. It was intended to complement this newtork with other regional radio stations, while increasing their transmission power?.

The core of the revised plan of accelerated, dynamic development of radio services was the construction of a central broadcasting station in Warsaw of great power at that time, i.e. $120 \mathrm{~kW}$, providing for detector reception across the country ${ }^{10}$. The idea

7 “Rocznik Polskiego Radia 1933”, Warsaw 1934, p. 10; Radio w Polsce w latach 1935-1938..., p. 139; M.J. Kwiatkowski, Narodziny Polskiego Radia..., p. 202; M.J. Kwiatkowski, Tu Polskie Radio Warszawa..., p. 378.

${ }^{8}$ L. Wicz, Wielki plan rozbudowy sieci radiofonicznej w Polsce, „Tygodnik Ilustrowany” 1927 nr 15, pp. 296-297; Najbliższe cele i zadania radiofonii w Polsce (wedtug miarodajnych źródet PR), „Radio” 1927 nr 14, p. 2; M.J. Kwiatkowski, To już historia..., pp. 65-67; M.J. Kwiatkowski, Narodziny Polskiego Radia..., pp. 286-288.

${ }^{9}$ Tes., Od fali 480 mtr. do fali 1111 mtr. Dwulecie radiofonii Polskiej, „Radio” 1928, nr 18, p. 2; Horoskopy na rok 1929, „Radio” 1929, nr 3, p. 2; Tes., Przyszłe oblicze radiofonii polskiej, „Radio” 1929, nr 26, p. 2; Idem, Kiedy wybudowane zostana nowe stacje nadawcze?, „Radio” 1929, nr 32, p. 4; Cała Polska na detektor. (Na marginesie rozbudowy sieci polskich stacji nadawczych). „Radio” 1929, nr 40, p. 2; Trzy nowe radiostacje polskie, „Radio” 1929, nr 51, p. 3; M.J. Kwiatkowski, Narodziny Polskiego Radia..., p. 286-287; M.J. Kwiatkowski, Tu Polskie Radio Warszawa..., Warszawa 1980, p. 265.

${ }^{10}$ An interview with the Polish Radio director Zygmunt Chamiec. Horoskopy na rok 1929, „Radio” 1929 nr 3, p. 2; M.J. Kwiatkowski, To już historia ..., pp. 109-112 
of building enormous radio stations in Poland was not a new one. Originally, from about 1924, it was being put forward by the representatives of the social movement of radio enthusiasts, still at the stage of a public exchange of views on a domestic radio model. They believed that under Polish circumstances it would be a very economical and rational choice, which they amply justified in numerous articles in the amateur radio press.

However, Zygmunt Chamiec, the PR director, had been a supporter of this idea since 1923, inspired by American standards after his reconnaissance in the United States ${ }^{11}$. This technical solution in a country with low electrification rates, especially in rural areas, ensured reception directly from the antenna in practice, even with simple and inexpensive detector receivers. Thus, stimulating the development of radio broadcasting, in addition to economic significance, automatically gained social importance. Undoubtedly, it was an act of a genuine radio democratisation process since it expanded the access to a modern informative, educational and cultural medium to an underprivileged social class because of poverty, illiteracy, living in remote areas and being removed from the centre in terms of advancement of civilization.

The ambitious long-term investment plan of Polish Radio was approved by the state shareholder represented by the Ministry of Posts and Telegraphs and confirmed in the new licensing Act of July 30,192912, adopted for as long as 20 years. The previous Act of August 18, $1925^{13}$, adopted for 10 years, was repealed. The licensee assumed the burden of the project "at its own expense and effort." In accordance with the approved plan and schedule it was required to: 1) build broadcasting stations of a particular power and run them within a specified time limit from the moment the licence was granted: in Warsaw (120 kW in the aerial within 18 months), Lviv (10 kW within 12 months) in Łódź (of not less than $0.5 \mathrm{~kW}$ within 12 months), a second one in Warsaw (of not less than $0.5 \mathrm{~kW}$ in a relay aerial within 12 months); 2) move the existing broadcasting equipment of the stations: from the Warsaw station to Vilnius or launch another radio station in Vilnius (of not less than $10 \mathrm{~kW}$ within 24 months), the Vilnius station to Torun and start it there as a relay station, or start another station in Torun (of not less than $0.5 \mathrm{~kW}$ within 28 months); 3) increase the power of the Poznań radio station (up to $10 \mathrm{~kW}$ in the aerial - begin rebuilding it no later than two years after the licence was signed and complete it within 12 months). After 340000 radio subscribers across the country were registered and their number increased by 20000 , the Minister for Posts and Telegraphs had the right to request the construction

${ }^{11}$ This opinion was expressed by Zofia Dziembowska who remained in a close relationship with the Chamiec family. Ryszard Miazek, op. cit., p. 162

${ }^{12}$ Akt koncesyjny z 30 lipca 1929 r., Dziennik Ustaw Rzeczpospolitej Polskiej; Archiwum Dokumentacji Aktowej TVP S.A., sygn. 9/2/Inw.gr.rz. 010. org. Komitet ds. Radia i Telewizji.

${ }^{13}$ Akt koncesyjny z 18 VIII 1925 r., for unknown reasons was not published in „Monitor Polski”. This document (from Archiwum Akt Nowych Prezydium Rady Ministrów - Akta Komitetu Ekonomicznego Ministrów 1920 - 1939, syg. 35, mikrofilm 25995) has been made public by Ryszard Miazek, Przeminęło z radiem..., pp. 281-293. 
of subsequent relay radio stations with a power of at least $0.5 \mathrm{~kW}$ - until a total of 30 independent and relay stations was reached. In addition, all broadcasting stations were to be equipped with receivers that met advanced technical standards ${ }^{14}$.

According to family accounts, it was Zygmunt Chamiec who was the initiator of an investment program estimated at around 10 million zlotys at that time, and the new licensing act imposing strict demands on the construction, modernisation and completion dates of specific radio facilities. The risk associated with the scale and pace of the investment was calculated rationally, still in good economic times. A long-term guarantee of profits for the shareholders and stability of the enterprise on the market was at stake ${ }^{15}$.

The financial plan for the gradual development and modernisation of the radio services was made formal in September 1929. The 8\% debenture loan was accepted as a source of repayment. At the same time foreign partners were acquired for the project, a co-contractor - MARCONIS Wireless Telegraph Co. Ltd. and Westminster Bank in London ${ }^{16}$. The state shareholder of Polish Radio S.A. did not contribute directly to the investment. To make up for it, in 1929-1933 it gave up a part of its profits from subscription fees ${ }^{17}$.

The most important facility to ensure the success of the plan, i.e. the central high-powered broadcasting station in Raszyn near Warsaw, was built within one year, efficiently and according to the schedule. At the end of 1930, it was possible to start the trial run, and on May 24, 1931 to officially launch the Raszyn radio station, which placed Poland in the leading group of countries with the most modern broadcasting stations. Its signal reached far beyond the borders, and the average range extended to $300 \mathrm{~km}$ for a detector and $4000 \mathrm{~km}$ for a tube receiver ${ }^{18}$.

The use of these impressive technical parameters of Raszyn and other newly built or upgraded stations and the actual popularisation of the radio among the masses was conditioned by the launch of affordable radio sets onto the market. This was because one of the barriers to the development of the national broadcasting was created by foreign corporations which monopolised the production and charged high prices of radio sets, and especially of radio tubes. Therefore, in parallel with the expansion of

${ }^{14}$ Akt koncesyjny z 30 lipca 1929 r., ..., art. 2, 4; M.J. Kwiatkowski, Tu Polskie Radio Warszawa..., pp. 143-145.

${ }^{15}$ R. Miazek, op. cit., pp. 162-164.

${ }^{16}$ The issue of debentures was decided on September 9, 1929 by the General Meeting of Shareholders and the Board of Governors of the Polish Radio Joint Stock Company. The Minister of Treasury authorized broadcasting on September 17 and the contract with foreign partners was signed on September 20. The repayment of the loan was spread over the years 1933 to 1942 . M. J. Kwiatkowski, Tu Polskie Radio Warszawa..., pp. 149-150.

${ }^{17}$ Normally the state was entitled to $20 \%$ of subscription revenues, and the licensee to $80 \%$. Because of the relief the government renounced 5\% from 1929 to 1932, followed by 2.5\% from October 1932 to October 1933 M. J. Kwiatkowski, Tu Polskie Radio Warszawa ..., pp. 147-148.

${ }^{18}$ R. Miazek, op. cit., p. 163. 
the broadcasting and relay stations, PR intended to implement the idea of a cheap radio set manufactured in Poland. In consultation with Chamiec, the director, the matter was dealt with by Eng. Roman Rudniewski (a commercial director of the National Association of Radio Engineering, and after the collapse of the company in 1928, an employee of Marconi Works (Zakłady Marconiego in Warsaw). To this end, he developed a plan, submitted on May 31, 1929 to the technical committee of PR, which assumed an annual production of 30-50 thousand detector radios, manufactured at a price of 38 zlotys, and sold at 48 zlotys, with the possibility of paying for them in monthly instalments at post offices. The mass production of Detefon ${ }^{19}$, the radio constructed by engineer Wilhelm Rotkiewicz, was developed in collaboration with Eng. Czeslaw Rajski, launched in 1930 in the National Communications Works (Państwowa Wytwórnia Łaczności) (since 1932 the National Tele and Radiotechnical Works (Państwowa Wytwórnia Aparatów Telegraficznych i Telefonicznych), and created under the merger of the National Communications Works and the National Telegraph and the Telephone Apparatus Works. Popular detector receivers started to be sold before Christmas in December 1930 under the slogan "Detefon for everyone in Poland." Both regular and less common distribution channels were used for the product, which could not only be purchased in shops but also in PR institutions and in all 3600 post offices across the country. The sets offered at the price of 39 zlotys, with an antenna, headphones and insulators, enjoyed popularity and were sold until the outbreak of the war, with the momentary collapse of sales in 1932, during the period of the most severe economic crisis. The radio was extremely successful and perfectly suited the needs and financial capabilities of the average customer, and therefore played a significant role in the popularisation of the radio in Poland. In the first two years 70000 sets - by September 1936, 152 000, and a total of up to 500 000-550 000 by 1939 — "Detefon" detector receivers of domestic origin were manufactured and sold ${ }^{20}$.

Proportionately to the progress of radio services, Poland inevitably became drawn into the area of propaganda and ideological war on the airwaves. Neighbouring countries, far more advanced in terms of radio services, ruled over the neighbouring territory on air. The real external pressure was expressed, among others, by the range of a German radio stations (Koenigswusterhausen near Berlin, Wroclaw, Gliwice,

\footnotetext{
${ }^{19}$ Detefon was registered in the Patent Office on Jan. 9, 1931, and soon became the most popular radio set in interwar Poland. M.J. Kwiatkowski, Polskie Radio 1925-1939..., p. 391-392; M.J. Kwiatkowski, Tu Polskie Radio Warszawa ..., pp. 151-153; R. Miazek, op. cit., pp. 166-168. The monographs of Roman Stinzing, Eugeniusz Szczygieł and Henryk Berezowski were devoted to the development of Polish radio engineering in the mid-war period, Zlote lata radia w II Rzeczypospolitej, Nowy Sącz 2000.

${ }^{20}$ M.J. Kwiatkowski, Polskie Radio 1925-1939..., p. 402; M.J. Kwiatkowski, Tu Polskie Radio Warszawa..., p. 153; R. Miazek, op. cit., p.168; Osiemdziesią lat Polskiego Radia. Kalendarium 1925-2005, Polskie Radio SA, p. 24.
} 
Königsberg and Danzig) audible on $3 / 4$ of Polish territory on one-tube radios across almost the entire Wielkopolska (Greater Poland) region and on the detectors in Silesia.

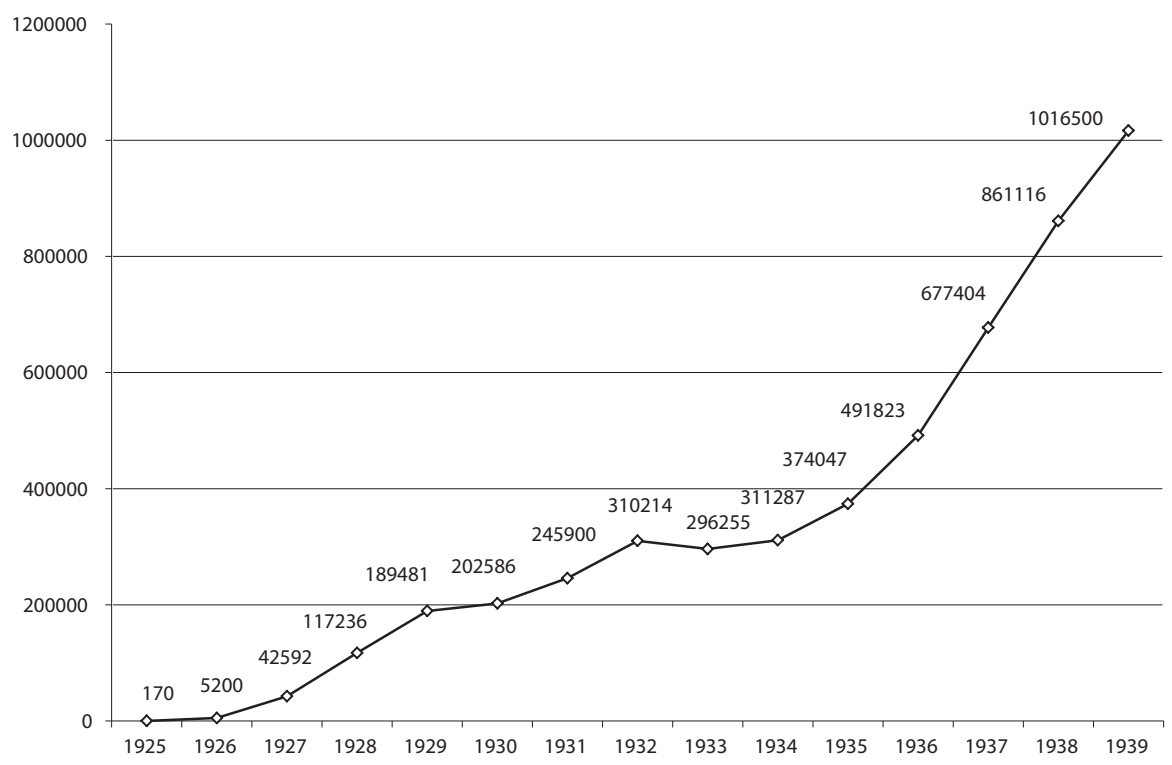

Fig. 1. Polish Radio subscribers.

Source: Radio w Polsce w latach 1935-1939, ed. F. Pawliszak, Warszawa 1938, p. 139.

Lithuania and the Soviet Union resorted to a similar invasion on air in the eastern reaches of the country. Thus, ever since the beginning of Polish Radio it faced an urgent challenge of responding to hostile propaganda broadcast by radio stations in neighbouring countries ${ }^{21}$.

Upper Silesia, divided between Germany and Poland, was the typical area of propaganda rivalry and sharp skirmishes on air. The answer to the expansiveness of the German radio station in Gliwice was the launch of the fourth broadcasting station of PR in Katowice on November 27, 1927. The campaign to commission the facility quickly was run by the Consul General in Bytom and a representative of the Mixed Commission for Upper Silesia, Dr. A. Szczepański, as well as local activists. The Silesian Treasury contributed considerably to the investment with a loan of 600000 zlotys. The ceremonial inauguration with Silesian authorities and PR management present was organized on Miners' Day on December 4, 1927. “Our propaganda is

${ }^{21}$ On the hostile propaganda by radio stations in neighbouring countries M. Stępowski, Radio jako czynnik polskiej propagandy zagranicznej, „Radiofon Polski” 1926 nr 13; M.J. Kwiatkowski, Narodziny Polskiego radia ..., pp. 221-223, 254-256, 260-262; E. Kaszuba, op. cit., pp. 135-141. 
not about scuffling and slandering others, offending anyone's national sentiments or convictions. The propaganda of the Polish culture and the propaganda of the state will only make use of noble thoughts of our scholars, inspired words of our poets and harmonious songs of our bards." ${ }^{22}$ So said the then chief executive of PR, Z. Chamiec, interjecting a clear hint at the "barrier" anti-sabotage role of the newly opened radio station. The manoeuvre was an effective one, as a $12 \mathrm{~kW}$ radio station - powerful at that time - in Katowice, indirectly led to "downgrading" Gliwice to the rank of a relay station. Prof. Stanislaw Ligoń was a recognised and much appreciated figure in Silesia, known as "Karlik z Kocyndra," who earned his renown with the narratives in a Silesian dialect of "Bery i bojki" (Silesian fairy tales) and "W niedziela przy żeleźnioku" (Sundays at a belly-stove) series. In 1939 Germans were to prove extremely unforgiving to persons distinguished in the propaganda struggle for Polish influence over Silesia. On entering Katowice they launched a search for Ligoń who fortunately lived in Warsaw at that time and managed to avoid persecution ${ }^{23}$.

In the late ' 30 s the approaching armed confrontation gave the term "war on air" a more literal meaning. Shortly before the disaster, at the beginning of 1939, Brig. Władysław Bortnowski spoke to his superiors as a spokesman for the Corps District VIII Commander's (DOK) plan for the reorganisation of broadcasting in Pomerania. The project encompassed two broadcasting centres in the region - on the coast (in Gdynia Oksywie) and the centre (in Toruń). The purpose of the specific solution was to transfer the existing radio station in Torun to the coast of Poland and build a new, at least $50 \mathrm{~kW}$ one in its place. The plan was presented as very important and urgent for operational and propaganda reasons. In support of the proposed changes it read as follows: "These broadcasting stations should enable detector reception in the entire Pomerania region, and their range should reach as deeply as possible beyond the cordons (East Prussia and Danzig) or hold a suitable diversionary force in these areas. This mainly concerns the radio station in Gdynia because of the newly built station in Slupsk (Stolp). ${ }^{24}$

The introduction of different subscription rates in Poland (Regulation of the Minister of Posts and Telegraphs, published in the Journal of Laws of October 13, 1936), i.e. 1 zloty for detector radios and 3 zlotys for more modern and efficient tube radios, was to help expand the level of radio services, yet, it brought surprising and harmful side effects. The predominantly poor population in the east opted for a cheaper option, even at the expense of quality. To make matters worse, in the Eastern Borderlands it was easier to receive Soviet broadcasts than the domestic ones on the detectors. In

${ }^{22}$ Hallo! Hallo! Polskie Radio - Katowice. „, RA” na uroczystem otwarciu radiostacji katowickiej, „Radio” 1927 nr 50, p. 2.

${ }^{23}$ On the radio station in Katowice, see especially M.J. Kwiatkowski, Narodziny Polskiego Radia ..., pp. 254-269.

${ }^{24}$ Sprawa Rozgłośni Pomorskiej. Generat do Prac przy GISZ w Toruniu do Szefa Sztabu Głównego przez Szefa Biura Inspekcji GISZ, Torun, 13 II 1939, Centralne Archiwum Wojskowe Biuro Inspektora Generalnego Inspektoratu Sił Zbrojnych, sygn. I 302.4.1638; E. Kaszuba, op. cit., p. 137. 
the eastern Volhynia and Polesie region the reception of Polish radio stations on detector receivers was completely jammed. The Soviet Union was eager to use station transmitters of greater power than the Polish ones to export destructive propaganda, winning the complicated ethnic, religious and social relations of the eastern border against the Polish state. An intense pro-communist campaign was carried out by means of special radio broadcasts in Ukrainian and Polish. Warnings and appeals reached the central government from the endangered region: "For the good of the Polish state and its citizens living in the eastern borderlands, radical steps should be taken to recover the situation by:

1. Granting privileges to all subscribers with tube receivers, residing in the $200 \mathrm{~km}$-wide eastern frontier strip by lowering the monthly subscription fee to 1 zloty.

2. Starting several ancillary radio stations on our eastern border in the near future, significantly strengthening the power of Polish radio stations (for strong detector reception).

3. Aiming towards a greater difference in wavelength between our stations and powerful frontier USSR broadcasting stations, to prevent the latter from jamming our broadcasts by consistent and blatant communist propaganda (...) by means of domestic detector radios currently favoured and widely purchased by the rural population. A considerable interest in these Soviet propaganda programs, which are only received by owners of detector radios, is already noticeable in the Volhynia region among the non-Polish rural population, and even a part of the Polish population (...). There is a skilful and elusive campaign carried out in order to encourage consumers to purchase detector receivers." 25

Around the same time the Ministry of Military Affairs was alerted to reports of a sharp increase in the number of radios in Volhynia, which seemed to be "unusual in times of crisis" and gave rise to a suspicion that those radios might be sent from behind the enemy cordon for the benefit of hostile propaganda ${ }^{26}$. The Corps District II Commander (Lublin), investigating the causes of the phenomenon at the behest of the headquarters, attributed an increase in the number of radios disproportionate to the year 1935 to their more attractive terms of purchase, especially concerning detefons, and the growing popularity of the radio. Moreover, the disparity disturbing the highest military ranks was somewhat superficial and resulted from the fact that it was only in 1936 that military statistics on radio services were compiled. In previous years the Corps District Commander did not have access to complete data, because

${ }^{25}$ Uwagi o wykorzystaniu odbiorników radiowych detektorowych na kresach wschodnich dla propagandy komunistycznej, prowadzonej przez stacje nadawcze ZSRR, podpor. rezerwy B. Podhorski, 3 XII 1936, CAW GISZ, sygn. I 302. 2. 1; E. Kaszuba, op. cit., pp. 138-139. More about the Soviet radio propaganda in Volhynia region: A.J. Cieślikowa, O radio dla Kresów. Radiofonizacja i plany budowy rozgłośni polskiego radia na Wołyniu w latach 30. XX wieku, „Z dziejów polskiej radiofonii” rocznik 2005/2006, nr 2, Warszawa 2005, pp. 165-167.

${ }^{26}$ MSWojsk. Gab. Min. do Dowódcy Okręgu Korpusu II Lublin, 1 VII 1936, CAW Dowództwo Okręgu Korpusu II, sygn. I 371.2.173; E. Kaszuba, op. cit., p.139. 
post offices did not forward (for approval) applications for permission to purchase a radio set. In the report the commander also stressed that "before they are allowed to purchase a radio, the people of the border districts are evaluated by the respective heads of the intelligence branches and the Border Protection Corps and if there is any suspicion that a radio set can be used against the state, permits are not granted, or those already granted are withdrawn at my request." 27

In the search for effective ways of blocking unwanted influence and yet maintaining the usability of cheap detectors with a low subscription fee, the PR opted for investing in modern broadcasting stations equipped with technological innovations in the eastern parts of the country. The transmitting power of radio stations in Vilnius and Lviv modernised in 1936 and of the two newly built ones - from autumn 1937 in Baranovichi and from 1938 in Lutsk - was set at $50 \mathrm{~kW}$. This was the result of the sufficient range and moderate operating costs (the larger the power of the radio station, the more expensive its use). Four powerful radio stations with a total power of 200 $\mathrm{kW}$ in the aerial was a "bastion of the Polish culture on the eastern border." ${ }^{28}$ Vilnius was the showcase illustrating the effectiveness of the technical solutions. "The Vilnius radio as a borderland station has a number of major tasks to fulfil in its work. Having 50 kilowatts at its disposal, the radio station is now able to resist the hostile campaign against Poland carried out by the radio station in Kaunas. The Lithuanian station quite regularly broadcast false and defamatory readings and lectures against Poland, and especially against the Vilnius region, which although presented in an unacceptable way in terms of European relations, prompted a dignified response from the Vilnius radio station, all the more effective as it used the register of the civilised world. However, the other important function of the Vilnius radio station is as a counterbalance to frontier propaganda of the Soviet radio station in Minsk, which is constantly broadcasting programs in Polish, flooding our borderlands with communist propaganda slogans, deluding people of still little awareness. The response of our Station, which does not resort to insults, slanders and calumnies, but only uses factual and accurate material - yields the expected results and paralyses radio propaganda hostile to us." 29

Of course, no modernisation of the radio transmission system could lead to a complete elimination of the influx and reception of foreign propaganda. In 1938, the Corps District II Commander in Lublin, Brig. Brunon Olbrycht, a supporter of radical solutions to issues deemed anti-state and anti-Polish, reported as follows: “... I'm getting a great number of alarming reports from the leaders of the field work that the Bolsheviks are carrying out a major campaign on the radio. The instigators

\footnotetext{
${ }^{27}$ Napływ radioaparatów na Wołyniu, DOK II do I Wiceministra Spraw Wojskowych Wydział Bezpieczeństwa, czerwiec 1937, CAW DOK II, sygn. I 371.2.173.

${ }^{28}$ Radio w Polsce w latach 1935-1938..., pp. 114-115, 127-128.

${ }^{29}$ Radio - Informator. Kalendarz przewodnik radiostuchacza na rok 1938, ed. E. Świerczewski, Warszawa 1938, p. 28; on the Vilnius radio station, see: Dziesięć lat Rozgłośni Wileńskiej, Wilno 1937.
} 
of Ukrainian and communist campaigns have tube radios and gather groups of people to listen to the radio. It is necessary to counteract by:

a) building a radio station as soon as possible or strengthening any other station in order to jam the Russian ones,

b) refusing subscription to people in any way uncertain,

c) punishing agitators for illegal meetings, and for listening to the radio or lending radios to others who have not paid for it and taking it as an excuse to confiscate or withdraw subscription rights. I believe that this issue should be dealt with in earnest." 30 It seemed as though the initiator had not noticed that it was on his area where Polish radio stations had been being strengthened for some years now - by starting the other regional station with a power of $50 \mathrm{~kW}$ in Vilnius in the autumn of 1936, and the construction of a new radio station in Baranovichi of the same power, which was to be commissioned on July 1, 1938. In addition, the proposals of using administrative harassment interfered as much with the campaign to expand radio services to the borderlands supported by the state as with guarantees of basic civil rights and liberties. Yet, they coincided with the pragmatics of the restitution movement rampant in the Chełm region at that time, which was clearly favoured General Olbrycht. ${ }^{31}$

Just before the outbreak of the war, Polish Radio boasted ten stations in the main cities of the country, with a total transmitting power of $424 \mathrm{~kW}$. In 1927, radio stations were launched in Cracow (February 15), Poznań (April 24), Katowice (November 27) and a year later in Vilnius (January 15). In 1930 stations in Lviv (January 15) and Łódź (February 2) were established. Starting the central radio station in Raszyn near Warsaw on May 24, 1931 with a range covering almost all Polish territory was an important event as well as a technological achievement. On January 15, 1935 a radio station was located in Torun, on March 15, 1937 in Warsaw II and on July 31, 1938 in Baranovichi. In 1939, the last enterprise of this type, i.e. a radio station in Lutsk, underwent technical tests before the launch scheduled for autumn, and the station in Raszyn was modernized with a view to increasing its transmitting power to 300 - and in the future up to $600 \mathrm{~kW}^{32}$.

Launching a shortwave station (SPW) owned by the Ministry of Posts and Telegraphs provided for broadcasting individual programs intended for the Polish population in America. In March 1936, it started broadcasting trial programs, then broadcast three times a week, and from May also on Sundays and holidays. From October 3, 1937, when the second shortwave station (SPD) was launched, every day at midnight Polish Radio broadcast a 2-hour program on weekdays, and a 3-hour one on Saturdays and Sundays across the Western Hemisphere. Due to the time difference between Warsaw

\footnotetext{
${ }^{30}$ Dowódca Okręgu Korpusu Nr II w Lublinie do Dowództwa 3 Dywizji Piechoty Legionów, Zamość, dnia 24 marca 1938 r., CAW II Oddział Szt. Gł., sygn. 1775/89/713.

${ }^{31}$ E. Kaszuba, op. cit., pp. 140-141.

${ }^{32}$ Radio w Polsce w latach 1935-1938..., pp. 24-34; M.J. Kwiatkowski, Tu Polskie Radio Warszawa..., p. 458.
} 
and New York it reached the target audience at 6 p.m. As part of the expansion by MP\&T in 1938 other short-wave stations were started: in August, a third and a fourth one intended for South America, and in October a fifth and a sixth one to reach across Europe. With six stations, the Polish Radio program reached the main centres of the Polish exiles in the United States, Brazil and European countries. At the end of the mid-war period, the main components of the Polish Radio broadcasts were $56 \%$ of music, $26 \%$ of readings and radio announcements, $5 \%$ of literary programs and $13 \%$ of other radio shows ${ }^{33}$.

The state had been committed to supporting the process of a dynamic development of radio services across Poland ever since the takeover of the radio in 1934. It made a special point of facilitating access to the media to the most numerous and usually the poorest social groups. In all provinces and districts the equivalents of the Public Committee for the Planned Development of Public Radio Services (Spoteczny Komitet Radiofonizacji Kraju) in Warsaw were quickly created. From 1934, special radio training courses qualified the teams of professionals to acquaint the public with the use of a radio set. Between 1935 and 1937 the PR instructors trained a total of about 10 thousand participants in 184 courses mentioned above ${ }^{34}$. Similar training was organised by the Public Committee for the Planned Development of Public Radio Services. Thus qualified radio technicians were commissioned to work in the field, particularly in rural areas. In a poor, post-crisis country, the campaign to expand radio services yielded visible, though still insufficient results. The growing number of newly registered subscribers in 1934 and 1935 amounted to an average of 100 thousand per year, while in the next two years amounted to 200 thousand. In 1937 in Poland, the number of radio subscribers increased by $27.14 \%$, i.e. more than in the leading European countries in terms of the degree of radio services at the time: England (6.52\%), Denmark (7.94\%), Germany (11.26\%) and Belgium (14.35\%). However, it is worth noting yet again that the starting point of the Second Polish Republic was far behind these countries. The average number of radios per 100 inhabitants of Poland in 1939 amounted to $3.1^{35}$. One of the attractive forms of radio promotion used by PR was rewarding every one hundred thousandth radio subscriber at registration. In mid-1938, with a population of 33 million Poland did not reach a million subscribers, but the number of listeners was estimated at several million. The millionth radio subscriber, Czesław Nowak from Stanisławów, was registered at the end of 1938/beginning of $1939^{36}$.

${ }^{33}$ Radio w Polsce w latach 1935-1938..., pp. 26, 86-87; Radio-Informator. Kalendarz przewodnik radiostuchacza na rok 1938..., pp. 16, 21-24, 26, 29-32, 35, 38-40; M.J. Kwiatkowski, To już historia..., p. 143-144; Osiemdziesiąt lat Polskiego Radia 1925-2005 ..., p. 33; E. Kaszuba, op. cit., p. 141-143.

${ }^{34}$ Radio $w$ Polsce 1935-1938 ..., pp. 132-133.

${ }^{35}$ Ibidem., pp. 138-139; M.J. Kwiatkowski, Tu Polskie Radio Warszawa..., pp. 377-380, 383, 431-432, 458-459.

${ }^{36}$ As every one hundred thousandth radio subscriber was acknowledged, the following persons received special recognition: Czeslaw Wadecki, a teacher from Siedlce as the four hundred thousandth subscriber in February 1935, Władysław Dunowski, a farmer from Nowa Wilejka as the five hundred 
Systematic and purposeful broadcasting for schools began in 1935/1936. The authority willingly sponsored initiatives to promote the radio at schools. It was in its interest to unify propaganda by promoting a specific profile of a young citizen of value to the state with the educational function of the school supported by PR. Radio employees developed a program section dedicated for children and teenagers, including educational programs, with the intention, among other things, to "instil social and civic instincts, love of the Fatherland, knowledge of the country and the Nation." School broadcasting was therefore inherently patriotic and ideology-ridden. In 1937, the radio particularly actively campaigned for the purpose of gifting schools, especially in the poorer eastern borderland regions, with radio sets. It also displayed an exemplary gesture of support, donating more than 300 radio sets to educational establishments. As part of the whole campaign, a new form of the inauguration of the school year 1937/1938 was adopted. For the first time on this occasion the Minister of Religious Denominations and Public Education spoke to students and teachers in front of the Polish Radio microphone. The repertoire intended for schools took nearly $3 \%$ of the total radio program. It was prepared according to the guidelines developed at joint conferences of Polish Radio and the Minister of Religious Denominations and Public Education. While promoting school broadcasting, PR supplied schools with a yearly schedule of school and educational broadcasts free of charge. At 8 a.m. it broadcast programs which included entertainment and news, but at 11.15 those related to the school curriculum. Airtime for the school programs was extended in the years 1935/1936 - 1937/1938 from less than 50 to more than 150 hours per year ${ }^{37}$.

High ranking officials hotly debated the issue of placing radio speakers in public places to ensure a greater number of people listening to the broadcast. They believed it was particularly important to introduce speakers in state and private enterprises, military units, public and secondary schools, municipal offices, community and youth centres, town markets, etc. In mid-1938 a satisfactory level and progress of radio services was reported only in one third (about 7 thousand) of elementary schools and military establishments. The armament industry was privileged in this respect, because it had to have an effective alarm system at its disposal, especially as far as air defence was concerned. Polish Radio pledged to commission cars equipped

thousandth subscriber in January 1936, Walerian Bagnucki, a policeman from Skarszewo as the six hundred thousandth subscriber in December 1936, Józef Kut, a priest from Kościerzyna on the Obra as the seven hundred thousandth subscriber in December 1937, Jan Okoński, a tram driver from Bydgoszcz as the nine hundred thousandth subscriber in February 1938, Radio w Polsce 1935-1938 ..., pp. 133-134; M.J. Kwiatkowski, Tu Polskie Radio Warszawa..., pp. 384-386; see information on Polish and European radio: Mały Rocznik Statystyczny Polski. Wrzesień 1939 - czerwiec 1941, Warszawa 1990, pp. 148-149 (the Polish edition of Concise Statistical Lear - Book of Poland. September 1939 - June 1941, published by the Polish Ministry of Information, London 1941).

${ }^{37}$ Radio w Polsce 1935-1938 ..., pp. 84-85; M.J. Kwiatkowski, Tu Polskie Radio Warszawa..., pp. 310-313, 386 . 
with loudspeakers, which could also function as portable exhibitions and points of equipment sale. The route of the PR cars with loudspeakers passed through areas with the fewest number of radios, identified on the basis of accurate statistical reports of the number of subscribers in each administrative unit. The most important mission of cars equipped with loudspeakers was, of course, on the eastern border area of the country ${ }^{38}$.

At the end of the 1930s insufficient electrification of the country and expensive radio equipment were cited as major obstacles to the progress of radio services. Philips cartel's monopoly on the production of radio tubes and their high prices inevitably escalated the cost of radio equipment manufactured in Poland. This situation worked against the plan proposed by the authorities to release a very cheap popular radio which would be affordable for the working classes onto the market. The proposals to address the problems and boost the expansion of Polish radio services included levelling subscription fees for all types of radios, without exception, to 1 zloty and the launch of low-cost American tubes or run this type of production by national manufacturers with considerable aid of the state. It was estimated that this could lead to lowering the prices of radios by up to $50 \%$, and the said popular radio would then become reality ${ }^{39}$.

The plan to develop radio services implemented in interwar Poland, although it did not reach an advanced stage that would ensure the freedom of communication, still yielded visible results. Between 1927 and 1939 the number of radio subscribers increased from 48 thousand to 1017 thousand, of which about 690 thousand were reported in the cities ${ }^{40}$. When it comes to the villages, the number of radio sets owned was more than half that in the city. The relatively fast pace of the development of radio services is illustrated by a comparison of the number of radios per 1000 inhabitants in the period roughly marking the beginning and end of the process during the mid-war period: 0.2 of a radio in 1926 and 30,91 radios in $1939^{41}$. On the eve of the war 187 radios per 1000 inhabitants in England, and 154 radios in Germany were recorded. Despite the disparities indicated, however, it is worth noting that in Poland with 30 million inhabitants at the beginning of 1939, one million subscribers were registered, thus constituting a far greater audience.

Finally, in terms of the development of radio services, the Second Polish Republic came in far behind the European leaders, in the 17th place ${ }^{42}$. However, taking into account its impoverishment, it still made considerable progress. The ambitious enterprise, strongly backed by the state since the turn of the decade, was conducted and completed in less than fifteen years, creating a technical base from scratch and

\footnotetext{
${ }^{38}$ Radio w Polsce 1935-1938 ..., p. 135.

${ }^{39}$ Protokót konferencji w sprawie popularnych audycji południowych Polskiego Radia - odbytej w MSWojsk. 24 V 1938 r., CAW Gab. MSWojsk., sygn. I 300.1.533; E. Kaszuba, op. cit., pp. 131-132.

${ }^{40}$ S. Miszczak, op. cit., pp. 179-180.

${ }^{41}$ Ibidem, p. 179; A. Paczkowski, op. cit, pp. 326-327; M.J. Kwiatkowski, Tu Polskie Radio Warszawa..., pp. 378-379.

${ }^{42}$ M.J. Kwiatkowski, Tu Polskie Radio Warszawa..., pp. 378; S. Miszczak, op. cit., p. 180.
} 
popularising the radio among the masses. The scale of the radio's impact was steadily increasing - thanks to the fact that the country was covered by a network of radio stations, the creation of regional stations, manufacturing and dissemination of cheap radios and improving the form and content of the broadcasts.

\section{References}

Akt koncesyjny z 30 lipca 1929 r., Dziennik Ustaw Rzeczpospolitej Polskiej.

Archiwum Dokumentacji Aktowej TVP S.A., sygn. 9/2/Inw.gr.rz. 010. org. Komitet ds. Radia i Telewizji.

Cała Polska na detektor (Na marginesie rozbudowy sieci polskich stacji nadawczych). „Radio” 1929, $\mathrm{nr} 40$.

Cieślikowa A.J., O radio dla Kresów. Radiofonizacja i plany budowy rozgłośni Polskiego Radia na Wołyniu w latach 30. XX wieku, „Z Dziejów Polskiej Radiofonii” 2005/2006, nr 2, Polskie Radio SA, Warszawa 2005.

Chomicz Z., Ziemianin w Radiu. Rozmowa z Ryszardem Miazkiem, „Z Dziejów Polskiej Radiofonii” 2004/2005, nr 1, Polskie Radio SA, Warszawa 2004.

Dowódca Okręgu Korpusu Nr II w Lublinie do Dowództwa 3 Dywizji Piechoty Legionów, Zamość, dnia 24 marca 1938 r., CAW II Oddział Szt. Gł., sygn. 1775/89/713.

Dziesięć lat Polskiego Radia, ed. W. Kłyszewski, Polskie Radio, Warszawa 1935.

Dziesięć lat Rozgłośni Wileńskiej, Polskie Radio, Wilno 1937.

Hallo! Hallo! Polskie Radio - Katowice. „,RA” na uroczystem otwarciu radiostacji katowickiej, „Radio" 1927, nr 50.

Horoskopy na rok 1929, „Radio” 1929, nr 3.

Kaszuba E., System propagandy obozu rzadzacego w Polsce w latach 1926-1939, Wydawnictwo Adam Marszałek, Toruń 2004.

Kiedy wybudowane zostana nowe stacje nadawcze?, „Radio” 1929, $\mathrm{nr} 32$.

Kwiatkowski M.J., Narodziny Polskiego Radia. Radiofonia w Polsce w latach 1918-1929, PWN, Warszawa 1972.

Kwiatkowski M.J., Polskie Radio 1925-1939. Mała kronika, „Pamiętnik Teatralny” 1973, z. 3-4.

Kwiatkowski M.J., To już historia. Felietony z dziejów Polskiego Radia, Wydawnictwa Radia i Telewizji, Warszawa 1975.

Kwiatkowski M.J., Tu Polskie Radio Warszawa..., Państwowy Instytut Wydawniczy, Warszawa 1980.

Mały Rocznik Statystyczny Polski. Wrzesień 1939-czerwiec 1941, Warszawa 1990 (Polish edition Concise Statistical Lear - Book of Poland. September 1939 - June 1941, published by the Polish Ministry of Information, London 1941).

Miazek R., Przeminęto z radiem. Opowieść o Zygmuncie Chamcu-założycielu i pierwszym dyrektorze Polskiego Radia, Wydawnictwo Szkoły Informatyki i Zarządzania, Rzeszów 2005.

Miszczak S., Historia radiofonii i telewizji w Polsce, Wydawnictwo Komunikacji i Łączności, Warszawa 1972.

MSWojsk. Gab. Min. do Dowódcy Okręgu Korpusu II Lublin, 1 VII 1936, CAW Dowództwo Okręgu Korpusu II, sygn. I 371.2.173.

Najbliższe cele i zadania radiofonii w Polsce (wedlug miarodajnych źródet PR), „Radio” 1927, nr 14.

Napływ radioaparatów na Wotyniu, DOK II do I Wiceministra Spraw Wojskowych Wydział Bezpieczeństwa, czerwiec 1937, CAW DOK II, sygn. I 371.2.173.

Od fali 480 mtr. do fali 1111 mtr. Dwulecie radiofonii Polskiej, „Radio” 1928, nr 18. 
Osiemdziesiat lat Polskiego Radia. Kalendarium 1925-2005, Polskie Radio SA., Warszawa 2005.

Paczkowski A., Prasa polska w latach 1918-1939, PWN, Warszawa 1980.

Protokót konferencji w sprawie popularnych audycji poludniowych Polskiego Radia - odbytej w MSWojsk. 24 V 1938 r., CAW Gab. MSWojsk., sygn. I 300.1.533.

Przyszłe oblicze radiofonii polskiej, „Radio” 1929, nr 26.

Radio - Informator. Kalendarz przewodnik radiostuchacza na rok 1938, ed. E. Świerczewski, Warszawa 1938.

Radio w Polsce w latach 1935-1938, ed. F. Pawliszak, Warszawa 1938.

"Rocznik Polskiego Radia 1933” No 1, Warszawa 1934.

Stinzing R., Szczygieł E., Berezowski H., Złote lata radia w II Rzeczypospolitej, VIDI, Nowy Sącz 2000 .

Sprawa Rozgłośni Pomorskiej. Generat do Prac przy GISZ w Toruniu do Szefa Sztabu Głównego przez Szefa Biura Inspekcji GISZ, Toruń, 13 II 1939, CAW, Biuro Inspektora Generalnego Inspektoratu Sił Zbrojnych, sygn. I 302.4.1638.

Stępowski M., Radio jako czynnik polskiej propagandy zagranicznej, „Radiofon Polski” 1926, nr 13. Trzy nowe radiostacje polskie, „Radio” 1929, nr 51.

Uwagi o wykorzystaniu odbiorników radiowych detektorowych na kresach wschodnich dla propagandy komunistycznej, prowadzonej przez stacje nadawcze ZSRR, podpor. rezerwy B. Podhorski, 3 XII 1936, CAW GISZ, sygn. I 302. 2. 1.

Wicz L., Wielki plan rozbudowy sieci radiofonicznej w Polsce, „Tygodnik Ilustrowany” 1927, nr 15.

\section{RADIOFONIZACJA II RZECZPOSPOLITEJ. PRZESLANKI SPOLECZNE, STRATEGICZNE I POLITYCZNE}

Streszczenie: W II Rzeczypospolitej do połowy lat dwudziestych radiofonia i radioodbiornik uchodziły za techniczną nowinkę. Zwrotu w tej dziedzinie miała dokonać dopiero spółka prywatno-państwowa Polskie Radio. Na mocy ogólnopolskiej państwowej koncesji na „broadcasting", czyli radio do masowego odbioru, uzyskanej 18 VIII 1925 r., stała się bowiem twórcą stałego polskiego radia i rozpoczęła proces radiofonizacji kraju. Stymulowanie rozwoju radiofonii - rozbudowa sieci radiofonicznej i upowszechnienie radia - oprócz znaczenia ekonomicznego, miało istotną wagę społeczną, strategiczną i polityczno-propagandową. Radio zapewniało znaczną swobodę komunikacji społecznej, w związku z tym mogło odegrać istotną rolę $\mathrm{w}$ integracji nowo odrodzonego państwa oraz poszerzyć dostęp do oświaty i kultury szerokim warstwom społecznym, także tym upośledzonym z powodu ubóstwa, analfabetyzmu i zamieszkiwania w rejonach cywilizacyjnie odstających od centrum. Musiało ponadto dawać odpór wrogiej propagandzie radiostacji państw ościennych, głównie Niemiec i Związku Radzieckiego, ale również małej Litwy. Ostatecznie II Rzeczpospolita dokonała istotnego postępu w dziedzinie radiofonizacji, tworząc od podstaw bazę techniczną i popularyzując radio wśród mas.

Słowa kluczowe: radiofonizacja, edukacja, propaganda, integracja. 